
Theoretical \& Applied Science

Feruz Boboyev

Junior Research Fellow

The Institute of History of the Academy of Sciences of Uzbekistan, Tashkent, Uzbekistan fbs2012@bk.ru

p-ISSN: 2308-4944 (print) e-ISSN: 2409-0085 (online)

Year: $2018 \quad$ Issue: $03 \quad$ Volume: 59

Published: 5.03.2018 $\quad$ http://T-Science.org

SECTION 13. Geography. History. Oceanology. Meteorology.

\title{
POLITICAL PROCESSES IN KASHKADARYA REGION AND ARMED STRUGGLE AGAINST THE SOVIET REGIME
}

Abstract: The article gives a brief analysis of the political processes and socio-economic situation in the Kashkadarya Region in the Soviet period, and enlightens some details of the armed struggle against the Soviet State in the region.

Key words: Uzbek SSR, Kashkadaryo Region, the Soviet Authority, political processes, economic situation, «the Basmachi Movement», political organization.

Language: English

Citation: Boboyev F (2018) POLITICAL PROCESSES IN KASHKADARYA REGION AND ARMED STRUGGLE AGAINST THE SOVIET REGIME. ISJ Theoretical \& Applied Science, 03 (59): 6-10.

Soi: http://s-o-i.org/1.1/TAS-03-59-2 Doi: crossef https://dx.doi.org/10.15863/TAS.2018.03.59.2

\section{Introduction}

The history of Soviet period of Uzbek SSR consists of complex, controversial historical processes. Analyzing and studying the essence and consequences of the reforms implemented in socioeconomic and political areas by Bolsheviks is one of the most actual issues the historians are facing at the present days. This article studies some aspects of political development and armed struggle against the Soviet regime in Kashkadarya Region.

\section{Materials and Methods}

Kashkadarya Region, one of the administrative units of Uzbekistan, established on November 1, 1924. It took a status of okrug on February 17, and kept it till 1927 January 15, 1938. On January 20 1943, it was reestablished as oblast[1, 622].

In 1925, Kashkadarya Region was divided into three uezds: Behbudi, Guzar and Shahrisabz. Behbudi City was the administrative center of the region [2, 343].

In $20-30$ s of $20^{\text {th }}$ century, Fergana Valley, Zerafshan and Surxon regions as well as Kashkadarya Region was among the areas of armed struggles against the Soviet regime. According to archival documents and press materials, the following qurbashis[3] red armed struggles against Soviets regime in Kashkadarya Region after 1925: 1. Tangri Berdi Dodkhoh in Yakkabog and Guzar; 2. Turdi Toqsabo in Behbudi; 3. Mohammed Ali Toqsabo in Shahrisabz; 4. Mulla Abduroziq in Kitob and Shahrisabz; 5. Mulla Eshqul Dodkhoh in Kirshak and Tangiharam; 6. Shohlibek in Guzar; 7. Shayman Toqsabo (a deputy of Tangri Berdi Dodkhoh) in Yakkabog; 8. Mavlonbek in Shahrisabz; 9. Jumabek in Guzar; 10. Mushmuhammad Hojiyev in Guzar; 11. Qora Chopon in Gizar; 12. Qadir Bek Polvon; 13. Chori Komandir (Commander).

Economic situation in Kashkadarya Region. The continuation of armed movements after 1925 Central Asian Soviet Republics was caused by fostering centralization and administrative command system in Soviet governing policy, considering of every republic in the USSR as raw material bases, spending all products that were produced in the republics in the interests of the Center, selfless labour of the population, underestimating their labor despite their hard work done day and night, unfair and disparagingly low payment for work and these

reasons raised fervent hatred against the policy of Soviet authority. Consequently, taking arms in hands, the population joined the armed movement to struggle against such policy, which had started seven years ago continued after that.

Continuation of the armed struggles against the Soviet regime in Kashkadarya Region after 1925 was caused by failure of social and economic situation and deterioration of living conditions that in turn caused the armed struggle to be reactivated with new power.

According to archival documents, in 1925 starvation and shortage of livelihood could be 
revealed in Kashkadarya Region. This situation can be explained by that, firstly, major part of the fertile lands of the region had been allocated under cotton growing. Cotton overgrowing caused rough reduction of grain seeding. Secondly, acquisition of the significant part of the produced grain in profit of state and mismanagement in the irrigation system caused dramatic reduction of yields. For instance, while there was gathered 3150 tons of cotton in 1926, this output reached 5795 tons in 1927. In 1928, the cotton was sewed in 12.6 thousand hectares, which was as 6 times more than in 1913[4, 51].

On the one hand, growth of cotton yield was reached because of increasing fertile land oriented in cotton, on the other hand selfless labor of Kashkadarya Region's population. Facing failure of crops in spite of hard labor, the population of Guzar had to leave their homeland and resettle to other lands. Particularly, the failure of crops made population to emigrate to Behbudiy Uezd. That situation caused increase of the number of fighters under Shohlibek, the leading qurbashi of Kungirat $\operatorname{kin}[5,32]$.

According to the archival documents of 1925 , it can be assessed that the "Basmachi" Movement became more active than in previous time and the qurbashis enjoyed permanent support by their native kin. The qurbashis saved their influence on population masses by authority figures of their kin. Failure in harvest and absence of livelihood, worsening of economic conditions forced several kinships to leave their home districts. For example, 450 households under Shohlibek Qurbashi of Kungirat kin left their homeland[6, 57].

The reason why anti-Soviet struggle been especially stiff namely in Guzar, was the deterioration of living conditions of peasants caused by devastation of agriculture. Therefore, the peasants joined the qurbashi troops, hoping to improve their life conditions. As a result, the peasants became the main leading power of the armed rebellion. Besides, Soviet government promised to render several economic aids and allow free farming to those peasants who severed themselves from the qurbashis' movements. However, these promises were not kept satisfactorily. Such situation is described in archival documents as follows: "condition of the peasants and others who left the movement is unsatisfactory and they are not sufficiently provided with family loans" $[6,57]$. If the Soviet government had satisfied daily living needs, there would not have happened armed struggles against Soviet regime or "Basmachi's Movement" as it was called in Soviet historical literature in the history in Central Asian republics.

Soviet government's undertakings to outfight the armed movement. The purpose of Soviet authorities to organize meetings and demonstrations among the population were firstly, to make people believe the armed struggle had been overpowered and instill such ideas in their minds and secondly, to defame qurbashis and keep population in fear by announcing judgments of court trials of seized qurbashi's and their troops in public.

On October 5, 1925, Muhammad Ali Toqsabo, who struggled against the Red Army in Shahrisabz area, arrived to Sinoboq Village located in 4 versts to the north of Shahrisabz. Spies informed the government that the qurbashi was in the village. In order to prevent Muhammad Ali Toqsabo from recruiting new troops and raising his status in the village, a Soviet commission came to Shahrisabz and held a meeting with 400 people on the same day. The meeting along with the "Committee for Fighting Basmachis' Movement" resolved to organize actions for outfighting the armed movement and define core essence of the movement no later than October 10[7, 23]. So, Muhammad Ali Toqsabo had to abandon the village.

The main subject of the meetings held on October 6, 1925 in Yortepe volost of Guzar Uezd and on October 7 in Tangiharam was to outfight the armed movement struggles against the Soviet regime. The meeting in Tangiharam was attended by local representatives of the "Committee for Fighting against Basmachis' Movement" from Guzar, Yortepe, Yangikent, Shorguzar, Beshchorbog, BeliBoyli, Kichi Oran, and Kirshak volosts[8, 24].

All the above-mentioned information shows that Soviet government established committees to fight against Basmachis' Movements everywhere and propagandized it broadly and publicly.

The Soviet government assigned certain people for intelligence service to detect the armed movement participants, their relatives and people supporting them and people being under suspect to be associated with the armed rebellion. They also created squads to seize and arrest "the Basmachis". Besides, the government performed training people for the intelligence service in Guzar. With the help of such squads, the government had arrested everyone somehow associated with qurbashis. The intelligence service had continuously spied upon all activity of qurbashis[7, 23].

Specific features of armed movement against the Soviet regime in Kashkadarya Region. Firstly, Mulla Abduroziq Qurbashi of Kashkadarya struggled against Red Army in two regions: Kashkadarya and Samarqand. The forces under Mulla Abduroziq consisted of two groups one of which led by him and the second - by Safar Yuzbashi (a commander of one hundred troops). Safar Yuzbashi was active across the Samarqand Region's border and Urgut Uezd of Samarqand Region[9, 317]. Mulla Abduroziq's troops clashed with the Red Army on March 24, 1925 in 25 versts to the northeast from Kitab. On March 31, Mulla Abdiroziq attacked a garrison of the 
Red Army in Gilon Village and demolished it completely.

Mulla Abduroziq had several clashes with the Red Army during the summer of 1926, too, and he was seized together with his four troops on August $14[10,2]$.

The second is characteristic not only with Kashkadarya Region but also with Zerafshan Valley. After 1925, the qurbashis did not all the time directly clashed with the Red Army[11, 139]. As Soviet Authorities had strong material and technical base, the qurbashis performed unexpected attacks to prevent significant losses. Comparing with the first stage of the armed struggle against the Soviet regime (1918-1924), during the second stage (1925-1935), the qurbashis had lower troops, suffering from rough deficiency of weapons, and the weapons they had were primitive and out-of-date. These factors caused the movement to be defeated in the struggle.

The third specific feature of the second stage of the armed struggles in Kashkadarya Region is that all influential qurbashis tried to extend their groups to as various areas as possible. The main purpose was to save from being detected by Soviet forces and intelligence and encounter troops of the Red Army. A tactic carried out by the qurbashis that was to divide large squads into smaller groups, on the one hand, had been found in the areas of military pressing by Turkestan Fronts troops and Muslim Cavalry brigades, and, on the other hand, was caused by some internal conflicts and clashes between qurbashis. Such condition was one of the most important reasons of collapse and loss of the armed struggle against the Soviet regime.

Economic support of the qurbashis. People provided economic needs of the qurbashis. The local people provided the qurbashis' troops with food and their horses with bait. After Soviets had revealed the situation, all the people associated with armed rebellion against the regime and their relatives under strong control and the people accused of being tied to the armed struggle were either severely punished or "de-kulakized". Since the Shahrisabz Uezd was on the border with Samarqand Region, the local people assisted the qurbashis to attack garrisons of the Red Army. The population secretly provided Mulla Abduroziq troops with food and bait. Intelligence service of Turkestan Front revealed the situation and the government launched a campaign against the local population supporting armed movements in order to cease and prevent support to qurbashis, demoralize and make them face worsening economic conditions $[12,56]$.

Another source of economic support of the qurbashis was levies collected among population. For example, Muhammad Ali Toqsabo collected 875 roubles[11, 139] as levies in Nushkent Village on December 31, 1925. Mulla Abduroziq levied 1000 roubles in Pistachi Poyon and Botkhona Villages located in 17 versts to the north-east, on June 4, 1926[13, 80].

Qurbashis' economic conditions was not always favorable. Moreover, launching of a punishment campaign against the population supporting the qurbashis caused further deterioration. Continuous military threat to the qurbashis from the Red Army and the existed economic conditions did not allow them to revive. Severe shortcomings of food made the qurbashis even stopping military activities. Togay Niyoz is one of such qurbashis. During previous activities, he delivered crushing blow on the Red Army. However, facing food shortage, he did not perform any activity at the end of 1925 and tried to hide out from the Red Army[14, 34].

Tangri Berdi Dodkhoh who was one of the famous qurbashis of the armed struggles in Kashkadarya Region forming his own squad in 1922 and led the clashes[15]. Tangri Berdi Dodkhoh unified groups struggling against the Red Army in Central Bukhara. In 1924, he, with the purpose of ending the war, initiated negotiations with the Soviet leaders and delivered strict requirements to the Soviet government. The government, not willing to observe his requirements, mobilized the army to fight against his troops. They tried several tactics to destroy his group. The government had even joined a secret agent among qurbashi's troops and made them work for Soviets[16].

The armed struggles were ideologically led by ulemas and religious figures. They were the qurbashi's councilors and escorts as well. TheSoviet government leaders also intended to eliminate such people. Musulmonqul, the adviser of Tangri Berdi Dodkhoh was arrested in Qalqa Village of Sharisabz Uezd[17].

Said Eshon (arrested in Autumn 1925) who served Tangri Berdi Dodkhoh enjoyed high position and reputation among the population. The qurbashi effectively used the service of the eshon (people believed to be direct descendants of the Prophet), who revealed the true basis of the Soviet government's policy and helped the qurbashi to involve people in the rebellion against the government[18, 254]. According to information of Turkestan Front of September 19, 1925, Tangri Berdi Dodkhoh prohibited people who joined the volunteer brigade of the Red Army to attend mosques willing to pray[19, 643].

Because of austere economic and military punishments performed against Tangri Berdi Dodkhoh during the second half of 1925, he had to move from Kashkadarya Region to Surxondaryo Region's areas settled by Kungirats[20]. After a certain period, it was revealed that Berdi Dodkhog returned to Ghuzar and the government's intelligence discovered him in Abduqandi Village on October 7, $1925[21,22]$. 
The main core of the armed struggles in Kashkadarya Region was qurbashis Berdi Dodkhoh, Mavlonbek and Mulla Abduroziq. According to the information of the Political Administration of Turkestan Front on October 10, 1925, qurbashis' 7 troops were killed and 6 ones were wounded in a clash between a joined squad of qurbashis (made of 80 troopers) and the Red Army[22, 646]. Tangri Berdi Dodkhoh was detained during one of the clashes in Kitob District on April 26, 1926 and later shot by the Soviet government.

Another leading qurbashi in Kashkadarya Region was Muhammad Ali Toqsabo, who commanded military movements in Yakkabog, Chiroqchi, Yortepe, and Shahrisabz districts. He led furious battles against the Red Army troops in Sinobok Village (four versts to the North from Shahrisabz) [7, 23] on October 5, 1925 and in Uchqol Village on December 21[11, 139]. Muhammad Ali Toqsabo, who conducted fierce battles until summer of 1926, moved to Kitob District to recruit new troopers on June 12. However, he was captured[23] in Chorshanba Village on June 17, 1926 and was killed by the Soviet regime.

The qurbashis of Kashkadarya had mutual friendy relations with qurbashis in neighboring areas. Leading qurbashis sometimes met and tried to solve various issues and made agreements on joint activities. Among other matters, regular meetings of Turdi Toqsabo, Mulla Eshqul, Tangri Berdi Dodkhoh and other qurbashis with Khurrambek can show it.

\section{Conclusion}

To sum up, the armed struggles against the Soviet regime in Kashkadarya Region were widely conducted and they always made the government suffer from severe quaking. The flip and flop policy pursued by the Central Government in the republics caused the armed struggles in which people of various social strata and nations joined. In Kashkadarya Region, Kungirat kin members of Uzbeks provided majority in rebels. Superior force of the enemy, absence of agreement and disputes between qurbashis led the struggle to be defeated.

\section{References:}

1. (2005) O’zbekiston milliy ensiklopediyasi. T. 10. - Toshkent: O’z ME nashriyoti, - p. 622.

2. (2018) President's Office Archive of Uzbekistan (Uzbekistan APO), Fond 58, Opis 1, Delo 623, L. 343.

3. (1917) "Qurbashi" is formed with two words, "qur" and "bashi" and means the leader of a certain group. In 1917, the head of city mirshabs (police) was called "qurbashi" in Qoqan, "duma" in Andijon, and "oqsoqol" in Osh. The Qurbashi Title had been assigned by "istiqlolchis" (fighters for independence) and Islamic Commanders-in -Chiefs. The title had been granted to large battalions commanders, only. Later, the commanders of a groups of 4050 troopers were also called qurbashis.

4. Ochilov M., Choriyev A. (1974) Qashqadaryo oblasti. - Toshkent: "O’zbekiston”, - p. 51.

5. (2018) Uzbekistan APO, Fond 58, Opis 1, Delo 618, L.32.

6. (2018) For more information see: Uzbekistan APO, Fond 58, Opis 1, Delo 696, L.57.

7. (2018) Uzbekistan APO, Fond 58, Opis 1, Delo 618, L. 23.

8. (2018) Uzbekistan APO, Fond 58, Opis 1, Delo 618, L. 24.
9. (2018) Uzbekistan APO, Fond 58, Opis 1, Delo 576, L. 317.

10. (2018) Uzbekistan APO, Fond 58, Opis 1, Delo 696, L. 2.

11. (2018) Uzbekistan APO, Fond 58, Opis 1, Delo 614, L.139.

12. (2018) Uzbekistan APO, Fond 58, Opis 1, Delo 696, L. 56.

13. (2018) Uzbekistan APO, Fond 58, Opis 1, Delo 625, L.80.

14. (2018) Uzbekistan APO, Fond 58, Opis 1, Delo 618, L. 34.

15. (1926) Konets glavy basmachestva Kashkadarinskiy oblasti // "Pravda Vostoka", № 99. 1 maya 1926.

16. (1925) See: Dodxohning jallodi // "Qizil O’zbekiston”, № 294. 1925 yil 6 dekabr.

17. (1925) Xabarchi.Bosmachilarning qanoti sindi // “Qizil O’zbekiston”, № 263. 1925 yil 28 oktyabr.

18. (2018) Uzbekistan APO, Fond 58, Opis 1, Delo 623, L. 254

19. (1973) Pogranichnye voyska SSSR 1918-1928. Sbornik dokumentov i materialov. - Moscow: «Nauka», - p. 643. 


\begin{tabular}{l|lr|ll|ll} 
& ISRA (India) & $=\mathbf{1 . 3 4 4}$ & SIS (USA) & $=\mathbf{0 . 9 1 2}$ & ICV (Poland) & $=\mathbf{6 . 6 3 0}$ \\
Impact Factor: & ISI (Dubai, UAE) $=\mathbf{0 . 8 2 9}$ & PUHЦ (Russia) $=\mathbf{0 . 2 0 7}$ & PIF (India) & $=\mathbf{1 . 9 4 0}$ \\
& GIF (Australia) & $\mathbf{0 . 5 6 4}$ & ESJI (KZ) & $=4.102$ & IBI (India) & $=\mathbf{4 . 2 6 0}$ \\
& JIF & $=\mathbf{1 . 5 0 0}$ & SJIF (Morocco) & $=\mathbf{2 . 0 3 1}$ & & \\
\hline
\end{tabular}

20. (1926) Polojenie na basmachestkami fronte // "Pravda Vostoka", № 43. 25 fevralya 1926.

21. (2018) Uzbekistan APO, Fond 58, Opis 1, Delo 618, L.22.
22. (1973) Pogranichnye voyska SSSR 1918-1928. Sbornik dokumentov i materialov. - Moscow: «Nauka», 1973. - p. 646.

23. (1926) Likvidatsiya ostatkov basmachestva // "Pravda Vostoka”, № 146. 30 iyunya 1926. 